УДК 552.54:552.14:553.08

\title{
УСЛОВИЯ ОБРАЗОВАНИЯ ВТОРИЧНЫХ ДОЛОМИТОВ В ПАЛЕОЗОЙСКИХ КАРБОНАТНЫХ КОЛЛЕКТОРАХ СЕВЕРО-ОСТАНИНСКОГО МЕСТОРОЖДЕНИЯ (ЗАПАДНАЯ СИБИРЬ) ПО ДАННЫМ МИКРОКРИОТЕРМОМЕТРИИ
}

\author{
Краснощекова Любовь Афанасьевна', \\ krasn!@tpu.ru
}

\author{
Аура Самид Гарсия Бальса', \\ garciaas@hw.tpu.ru
}

\author{
Белозёров Владимир Борисович1, \\ belozerovvb@hw.tpu.ru \\ 1 Национальный исследовательский Томский политехнический университет, \\ Россия, 634050, г. Томск, пр. Ленина, 30.
}

\begin{abstract}
Актуальность исследования определяется разработкой новой стратегии поиска залежей углеводородов в отложениях палеозойского комплекса, не связанных с эрозионно-тектоническими выступами фундамента, что обусловлено низкой эфрфективностью геологоразведочных работ, проводимых в пределах этих традиционных поисковых объектов. Учитывая значительное снижение нефртеперспективных структур, обеспечивающих прирост запасов углеводородов по отложениям платформенного чехла, выделение «неструктурных» поисковых объектов в породах фундамента на основе нового понимания процессов формирования карбонатных коллекторов палеозоя будет способствовать дальнейшему развитию нефртегазовой промышленности Западной Сибири.

Целью исследования является анализ новых данных о газово-жидких включениях в среднедевонских доломитах СевероОстанинской площади для изучения механизма доломитизации органогенных и органогенно-обломочных известняков, являющихся основным нефтеперспективным объектом палеозойского комплекса в пределах Нюрольской впадины.

объект исследования - карбонатные породы биогерма из двух скважин в кровельной части палеозойского фундамента (пласт $M_{1}$ ) Северо-Останинского нефтегазоконденсатного месторождения. В изученных скважинах органогенная постройка выходит на эрозионную поверхность фундамента и кровельная часть известняков интенсивно доломитизирована.

Методы: кристаллооптический (петрограсрический), микротермометрический, криотермометрический.

Результаты. Формирование коллекторов Северо-Останинского месторождения связано с процессами вторичной доломитизации органогенных и органогенно-обломочных известняков биогермной постройки палеозойского пласта М1. Крио- и термометрические исследования двухсазных первичных газово-жидких включений в кристаллах доломита позволили определить среднюю температуру их гомогенизации - $110-120^{\circ} \mathrm{C}$, и среднюю соленость растворов - 4,5 мас. \% экв. $\mathrm{NaCl}$, что может указывать на образование доломитов из умеренно-температурных растворов низкой солености, которые образуются в результате смешения просачивающихся с поверхности метеорных вод и гидротермальных источников по системе разломов. Растворы, дренируя коры выветривания основных по составу вулканитов, насыщают воды магнием и железом и способствуют доломитизации карбонатных пород.
\end{abstract}

\section{Ключевые слова:}

Микротермометрия, криотермометрия, газово-жидкие включения, доюрские карбонатные породы, доломит, Западная Сибирь.

\section{Введение}

Анализ газово-жидких включений (ГЖВ) при исследованиях в нефтяной геологии дает важную информацию о происходящих в породах коллекторов процессах и времени накопления углеводородов (УВ) в сложно построенных бассейнах $[1,2]$. Применение данного анализа позволяет получить сведения о древних осадочных флюидных средах (палеотемпература и палеодавление) [3-7]. При наличии во включениях крошечных жидких капсул нефти, помимо давления и температуры захвата УВ, возможно спрогнозировать источник их образования [8-13], а в случае извлечения и анализа нефти определить ее зрелость [9, 14-23].

Во время роста или рекристаллизации кристалла жидкая минералообразующая фаза может задерживаться в различных дефектах растущего минерала и сохраняться в полости после его дальнейшего роста. Газово-жидкие (флюидные) включения, сохранив- шиеся в герметично запечатанном состоянии в минерале, отражают первичный материнский раствор, из которого шла кристаллизация минерала, и являются прямыми свидетелями тех жидкостей, которые циркулировали и взаимодействовали с породой [24].

Микрообразцы жидкости во включениях, которые попадают в ловушку, отражают эволюцию флюидов осадочного бассейна, и анализ этих включений может быть использован для исследования состава жидкостей, связанных с диагенетическими и постдиагенетические флюидными процессами [25]. С начала 1990-х гг. метод микротермометрии стал одним из основных методов для прямого анализа доломитизирующих жидкостей при изучении нефтеносных отложений [26, 27].

Для уточнения источника и генезиса флюидов, из которых образуются доломиты в породах [28], провели изучение диагенетических изменений в доломито- 
вых толщах древней карбонатной формации Cupido северо-восточной Мексики. Исходя из петрографических данных, геометрии и распределения доломитовых тел, микротермометрических результатов флюидных включений (ФВ) и геохимической информации установлено, что доломитизация происходила в условиях диагенеза при глубоком захоронении осадков. Температуры гомогенизации в двухфазных флюидных включениях в замещающем доломите 190-200 ${ }^{\circ} \mathrm{C}$ интерпретированы как минимальные температуры для образования минерала.

В породах формации Dolomie de Mano на югозападе Франции по результатам исследований [29] установлены три диагенетических генерации доломита, две из которых связаны с зонами дробления. На основе анализа флюидных включений в доломитах сделаны выводы об их осаждении из слабо солевых гидротермальных растворов при температуре около $150{ }^{\circ} \mathrm{C}$, дополнительно определены условия давления (Р) и температуры (Т) путем моделирования данных по флюидным включениям, захваченным в минералах трещин (кальците и доломите) в этих мезозойских сериях.

В протерозойско-палеозойских морских карбонатных сукцессиях бассейна Сычуани в Китае, к которым приурочен газоносный пласт [30], для понимания механизма доломитизации на основе комплексного изучения петрологии, минералогии, геохимии, анализа структурных и осадочных обстановок выделили три группы седловидных доломитов. Микротермометрические измерения зональных кристаллов доломита показали, что температура флюидных включений в индивидах разных формаций выше нормальной температуры захоронения и температуры гомогенизации замещающих доломитов, что указывает на их гидротермальный генезис. Основываясь на последовательности диагенетических событий и геохимических данных, авторы пришли к выводу, что существуют различные источники и механизмы формирования гидротермальных доломитизирующих растворов и наблюдается последовательность между миграцией углеводородов и гидротермальной доломитизацией.

На одном из газовых месторождений в Персидском заливе, где более 60 \% пород залежи доломитизированы [31], собрали микротермометрические данные по газово-жидким включениям в минералах цемента кальциту и доломиту, которые вместе с петрографическим анализом позволили разделить все включения на три генерации. Температуры гомогенизации флюидных обособлений в цементирующих доломитах варьировали от 126 до $169{ }^{\circ} \mathrm{C}$, соленость палеорастворов составляла 16-17,5 мас. \% экв. $\mathrm{NaCl}$ (эквивалент $\mathrm{NaCl}$ ), что указывает на альтернативные источники формирования доломитов - от погребенных поровых вод до диагенетических высокотемпературных.

Уточнение источников палеофлюидов, из которых образуется доломит в карбонатных коллекторах, может дать важную информацию об эволюции растворов, их взаимодействии с породами во время диагене- за и процессах минерализации [32]. Представления о природе формирования и пространственной локализации доломита, как потенциально нефтеперспективного коллектора, позволяют выработать стратегию поисковых работ на нефть и газ в ловушках неструктурного типа.

Несмотря на то, что изучение месторождений нефти и газа в фундаменте Западно-Сибирской плиты ведется уже более полувека, процессы накопления углеводородов остаются не до конца ясными, в первую очередь, потому, что палеозойские отложения, залегая на больших глубинах, осложнены тектоническими нарушениями, проявлением метаморфизма и гипергенных процессов и представлены, как правило, сложными по генезису коллекторами. Это означает, что образовавшиеся резервуары нефти и газа подвергались многочисленным воздействиям, приводящим к разрушениям и возможному повторному накоплению углеводородов, тем самым скрывая историю их накопления.

Представленная работа является первым исследованием флюидных включений микротермометрическим методом в доломитах карбонатных коллекторов Северо-Останинского месторождения, которые и стали объектом исследования. Целью работы являлось получение данных о составе и температурном режиме минералообразующих сред, приводящих к развитию вторичного доломита в органогенно-обломочных известняках продуктивного пласта $\mathrm{M}_{1}$ месторождения.

\section{Геологическое строение месторождения}

Северо-Останинское нефтегазоконденсатное месторождение расположено в Парабельском районе Томской области, имеет площадь 1972 км², входит в Пудинскую группу месторождений углеводородов [33] (рис. 1,a).

Площадь характеризует залежи нефти палеозойского фундамента, которые не связаны с эрозионнотектоническими выступами и контролируются литологической неоднородностью в пределах отдельных блоков фундамента. По сейсмическому горизонту $\Phi_{2}$ (кровля доюрских образований) поднятие представляет собой тектонический блок, являющийся частью крупной тектонической зоны нефтегазонакопления, состоящей из локальных залежей, контролируемых дизъюнктивной тектоникой [34] (рис. 1, 6,8 ).

Продуктивные поисковые объекты доюрских отложений в пределах юго-восточной части ЗападноСибирской плиты представлены зоной контакта палеозойских и мезозойских отложений - нефтегазоносным горизонтом зоны контакта (НГГЗК) [35] и объектами глубинного палеозоя. В составе НГГЗК выделяют отложения коры выветривания (пласт М) и кровельную часть палеозойского фундамента (пласт $\left.\mathrm{M}_{1}\right)$, в глубинном палеозое - пласт $\mathrm{M}_{2}$.

Продуктивность на Северо-Останинском месторождении связывают с зоной доломитизации известняков биогермной постройки пласта $\mathrm{M}_{1}$ [36]. Разрез пласта сложен, преимущественно, карбонатными породами (доломитами; органогенными, доломитовыми, глинисто- и глинисто-кремнистыми известняками), 
аргиллитами с редкими прослоями основных вулканитов. Поисковые скважины вскрыли пласт, который не выдержан по мощности, что создает определенные трудности в корреляции биогермной постройки и продуктивных отложений на месторождении.

Проведёнными исследованиями по уточнению генезиса формирования доломитов на основе анализа газово-жидких включений установлены относительно низкотемпературные условия их образования, что связано с процессом поверхностного просачивания обогащённых магнием метеорно-гидротермальных вод по трещинам в органогенные известняки. При этом процессами доломитизации были охвачены структурные понижения, контролирующие зоны локализации сточных вод, что и способствовало формированию «неструктурной» литолого-тектонически экранированной, стратиграфической ловушки углеводородов, выявление которых требует проведения определённой последовательности геолого-геофизических исследований [37].
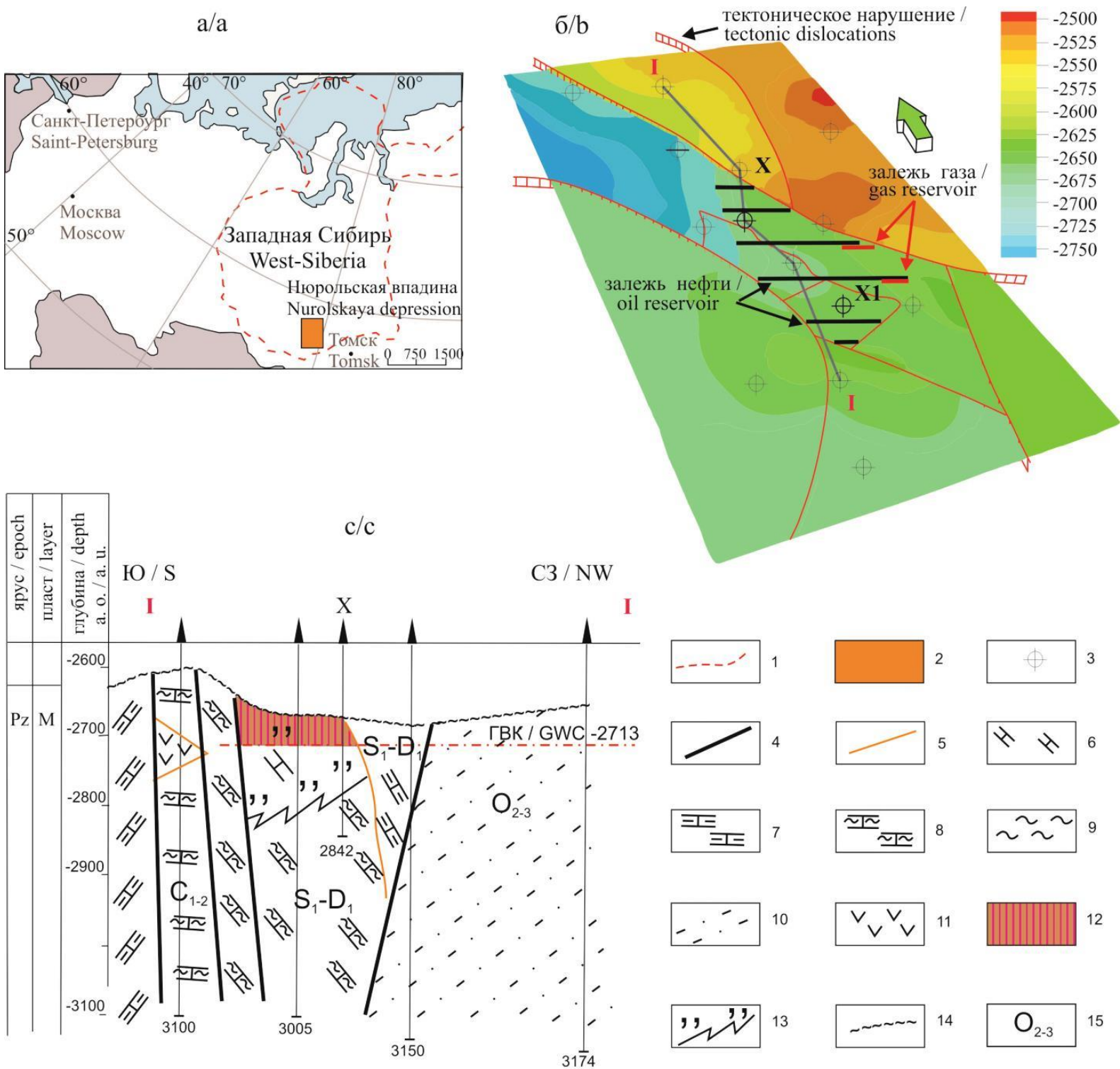

Pис. 1. а) схематичная карта расположения месторождения; б) геологическая модель на карте по кровле доюрских образований; с) геологический разрез по линий I-I. 1 - границуа нефтегазовой провинции; 2 - область исследования; 3-скважина; 4-тектонические нарушения; 5-литологические и фациальнье границь; 6известняк органогенный, биоморфный; 7 -известняк глинистый; 8-известняк кремнестый; 9 - глинистокремнистые породыл; 10 -алевролито-глинистые породыл (аргиллиты); 11 -эффузивнье породы; 12 газоконденсатное насыщение породы; 13 -участки вторичной проработки пород; 14-граница стратиграфического несогласия; 15 - возраст пород

Fig. 1. a) general location; b) geological model on the map the roof of pre-Jurassic formations; c) geological section along lines I-I. 1 - boundaries of oil and gas province; 2 - study area; 3 -well; 4 - tectonic disturbances; 5 - lithological and facial boundaries; 6 - organogenic limestone, biomorphic; 7 - clayey limestone; 8 - siliceous limestone; 9 clay-siliceous rocks; 10 - silt-clay rocks; 11 - effusive rocks; 12 - rock with gas condensate saturation; 13 secondary rock transformation; 14 - stratigraphic unconformity border; 15 - age of rocks 


\section{Образцы и методы исследований}

Из скважин X и X1 Северо-Останинского месторождения отобраны 26 образцов керна карбонатных пород с последующим их описанием и изготовлением шлифов. Последние окрашивались ализарином красным С для идентификации доломита и кальцита. Петрографическое изучение проводилось на оптическом поляризационном микроскопе Olympus ${ }^{\circledR}$ BX-53-F. Первый этап исследования, помимо определения минералогического состава и особенностей строения пород, заключался в поиске флюидных (газовожидких) включений в доломите и кальците, слагающих основную массу пород. При наличии флюидных включений в минералах шлифов отбирались репрезентативные образцы, содержащие несколько генераций доломита и кальцита, из которых изготавливались двусторонние полированные пластины толщиной 0,3 мм для определения микрокриотермометрических данных ГЖВ. Далее пластины отклеивались от стекла и промывались этиловым спиртом для удаления термоклея. Для установки препаратов в термокамеру от пластины механическим путем отделялись части с минералами, содержащими включения для исследования

Среди используемых методов для характеристики флюидных включений указанный метод является распространённым и наиболее полным методом, позволяющим количественно определять плотность флюида и его химический состав с точки зрения основных компонентов. Микротермометрические параметры определяются измерением температуры, при которой происходят фазовые изменения во флюиде, захваченном в полостях минералов при охлаждении и нагревании образца [38]. При отсутствии доказательств неоднородности предполагается, что жидкая среда, в которой росли кристаллы, была однородной при высокой температуре кристаллизации [39].

Выделение первичных флюидных включений в пластине проводилось в соответствии с критериями [4]. Исследовались 27 включений с определением 37 замеров температур фазовых переходов. В установленных первичных двухфазных ГЖВ в минералах измерялись температуры: эвтектики (плавления) $\left(\mathrm{T}_{\text {эвк }}\right)$, конечного таяния кристаллов льда $\left(\mathrm{T}_{\text {пл.л. }}(\right.$ лед $\left.)\right)$ и гомогенизации $\left(\mathrm{T}_{\text {гом }}\right)[40]$.

Температура эвтектики $\left(\mathrm{T}_{\text {эвm }}\right)$ показывает температуру плавления первой кристаллической фазы после полного замораживания. Этот параметр позволяет определять валовый состав включений.

Температура плавления льда $\left(\mathrm{T}_{\text {пл.л. }}\right)$ - температура плавления последнего кристалла льда, является показателем общей солености. Поскольку часто неизвестно, какие именно соли содержатся в изучаемых включениях, для выражения концентрации принято пользоваться понятием $\mathrm{NaCl}$ эквивалент (экв. $\mathrm{NaCl}$ ), где концентрацию соли определяют, принимая во внимание, что во включении присутствует только $\mathrm{NaCl}$. Выразить концентрацию в экв. $\mathrm{NaCl}$ при температурах ниже, чем $-5^{\circ} \mathrm{C}$, невозможно.
Температура гомогенизации $\left(\mathrm{T}_{\text {гом }}\right)$ фиксирует исчезновение газовой фазы во флюиде, т. е. происходит гомогенизация двух фаз, показывает начальные условия минералообразования и является минимальной температурой образования минерала (постулат Сорби). Это считается минимальным пределом, поскольку необходимо учитывать определенные аддитивные поправки при рассмотрении давления флюида во время роста, что облегчает захват включений при более высокой температуре, чем гомогенизация.

Пластины исследовались в системе, включающей термокамеру Lincam MDSG-600 со стадией нагрева/охлаждения, поляризационный микроскоп ZEISS Axio Scope.A1 и программу Linksys 32. Измерения температуры фазовых переходов определялись в режиме реального времени в интервале от -180 до $600{ }^{\circ} \mathrm{C}$. Нагрев и замораживание флюидных включений проводились при минимальной скорости охлаждения/нагревания 1 градус в минуту (в промежутках, близких к фазовым изменениям) и максимальной скоростью 10 градусов в минуту. Стандартные погрешности определения составляли $\pm 1{ }^{\circ} \mathrm{C}$ для температуры больше $100{ }^{\circ} \mathrm{C}$ и $\pm 0,2{ }^{\circ} \mathrm{C}$ для температуры меньше $0{ }^{\circ} \mathrm{C}$, соответственно, для температуры гомогенизации и конечного таяния льда

Каждое включение было подвергнуто термическому и криометрическому изучению, что впервые позволило провести анализ состава флюида и оценить возможные температуры среды минералообразования для доломитов и доломитизированных известняков Северо-Останинского месторождения.

Температура гомогенизации определялась при нагреве флюидных включений до исчезновения межфазовых границ.

По температурам эвтектики определялся солевой состав растворов [41], а по температуре плавления льда рассчитывалась концентрация солей включений [42]. Соленость раствора, соответствующая измеренной депрессии точки замерзания, рассчитывалась по формуле:

$$
\begin{gathered}
\text { Соленость }(\text { мас. } \% \mathrm{NaCl})= \\
=1,78 \times \mathrm{T}_{\text {пллл. }}-0,0442 \times\left(\mathrm{T}_{\text {пл.л. }}\right)^{2}+0,000557 \times\left(\mathrm{T}_{\text {пллл. }}\right)^{3},
\end{gathered}
$$

где $\mathrm{T}_{\text {пл.л. }}-$ депрессия точки замерзания (FPD) по Цельсию.

Расчет давления и плотности по известным переменным данным (температура гомогенизации и соленость) с использованием уравнения состояния [43] проводился в компьютерном пакете FLUIDS [44].

\section{Результаты и обсуждение}

\section{Петрография}

Палеозойские отложения Северо-Останинской площади вскрыты в 17 скважинах и представлены, преимущественно, карбонатными (известняки, доломиты, доломитизированные известняки) и глинистокремнистыми породами. Детально петрографически изучены 26 образцов пород из скв. X и X1.

$\mathrm{B}$ скв. Х исследуемый разрез сложен известняками органогенно-детритовыми, доломитизированными, 
известковистыми доломитами. Породы имеют массивную пятнистую прожилково-трещинную текстуру, часто развиты стилолитовые швы. В нижней части разреза в отдельных образцах стилолиты совместно со слоистостью, обусловленной пропиткой пород гематитом и развитием коричневатого глинистого вещества, располагаются под углом 45-65 к оси керна. Выделения гематита и битуминозного коричневатобурого вещества в породах не всегда позволяет их правильно идентифицировать. В этом случае для уточнения вещественного состава привлекались методы спектроскопии комбинационного рассеяния и люминесцентно-битуминологического анализа [36]. Битуминозность в породах скважин иногда отмечается в виде примазок, небольших сгустков, может наблюдаться в трещинном пространстве вместе с карбонатным агрегатом и составляет по данным люминесценции в среднем $0,02 \ldots 0,04 \%$
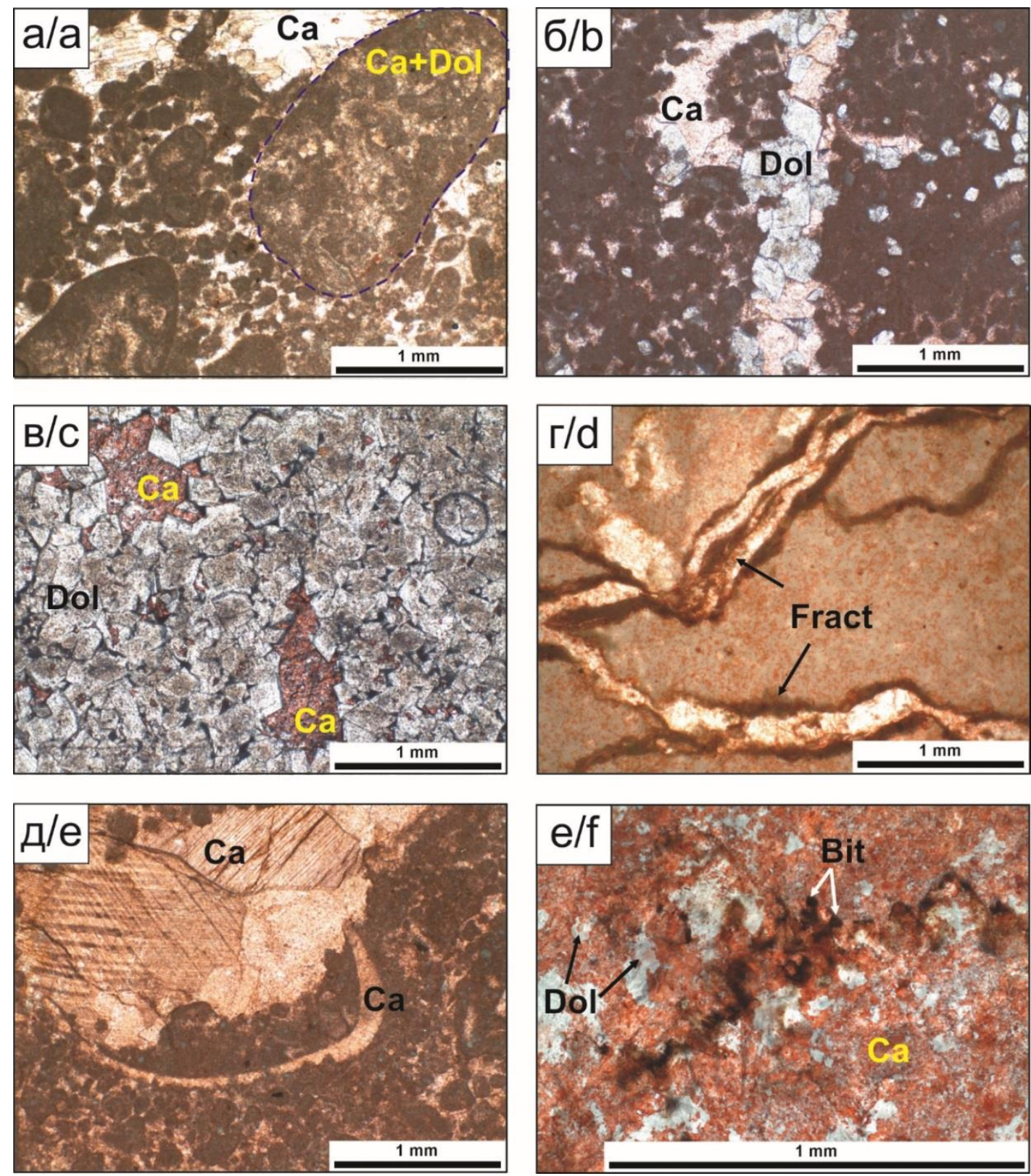

Pис. 2. Особенности строения и минералогического состава карбонатных пород Северо-Останинского месторождения в шлифах: а) форменные образования известняков; б) кристалль доломита в трещинах; в) доломитизациия пород - ромбоэдры доломита и поры с кальцитом; г) трещчины и стилолиты в карбонатных породах; д) обломки фауны с замещением и перекристаллизацией кальцита; е) пятна и сгустки битумоидов в породе. Ca - кальцичт, Dol-доломит, Bit - битумоиды, Fract-трещины. Фотографии без анализатора. Шлифы на рис. б-е прокрашены ализариновым краснымм

Fig. 2. Textural and mineralogical composition features of the carbonate rocks of the North-Ostaninsk field in thin sections: a) limestone occurrence; b) dolomite crystals-filled fracture; c) dolostone - dolomite rhomb developed and porefilling calcite; d) fractures and stylolites in carbonate rocks; e) skeletal fragmented shell debris showing pore-filling calcite cement and recrystallization; f) patch and clot bitumoid in the rocks. Ca - calcite, Dol-dolomite, Bit bitumoid, Fract-fractures. Photos under parallel Nichols. The sections in Fig. $b-f$ are stained with alizarin red 
В основной массе породы представлены форменные образования округлой и/или овальной формы, сложены коллоидно-и тонкозернистым кальцитом и доломитом (тип Д1) [36] (рис. 2, a). Они цементируются мелкокристаллическим кальцитом. Органогенные остатки раковинной (брахиопод, остракод, фораминифер) и единичных проявлений скелетной фауны (коралллов) имеют слабую сохранность, сильно микритизированы по краям кальцитом.

Пустотно-поровое пространство, трещины и мелкие каверны выполнены зернистым кальцитом и реже доломитом. Вдоль трещин часто фиксируется проявление ромбоэдрических кристаллов доломита (тип Д2) (рис. 2,б). Правильные или частично правильные ромбоэдры доломита (тип ДЗ) развиваются по основной массе породы и достигают $30 \ldots 40 \%$, в отдельных случаях фиксируются переходы в известковые доломиты (рис. 2, в). В ромбоэдрах доломита (Д2 и Д3) при исследовании шлифов отмечаются газовожидкие включения, имеющие при комнатной температуре двухфазовый состав.

В скв. Х1 отмечаются известняки пелитоморфные, органогенные и органогенно-обломочные, сгустковокомковатые, с неравномерными участками перекристаллизации и скоплениями остатков, формирующими пятнистую текстуру. В породах наблюдаются многочисленные ветвящиеся трещины и стилолиты (рис. 2, 2).

Пелитоморфное карбонатное вещество составляет $40 \ldots 70 \%$ от площади описываемых шлифов, образуя пелоидные, оолитовые и пизолитовые разнозернистые выделения. Органические остатки до 20-30\% представлены остракодами, водорослями, спикулами губок, неопределимыми обломками и выполняются кальцитом (рис. 2, )). Участки перекристаллизации среди комковатой массы и трещины сложены кристаллически зернистым кальцитом, содержание которого варьирует в пределах $10 . . .30 \%$. В образцах фиксируется пропитка основной массы гематитом, который и подчеркивает слоистое строение пород. В меньшей степени отмечается глинистое или хлоритглинистое вещество, к которому приурочен битуминозный компонент. Последний выделяется также в виде пятен, сгустков, обособлений в породах (рис. 2, e).

\section{Газово-жидкие включения в карбонатах}

Для изучения в зернистых агрегатах кальцита и доломита отбирались первичные флюидные включения, имеющие две фазы при комнатной температуре (жидкость+газ) с преобладанием жидкости (рис. 3). К сожалению, большая часть газово-жидких включений в кристаллическом доломите и кальците слишком малы для измерений. Однако те включения, где было возможно определить температурные параметры, имели, преимущественно, неправильную, прямоугольную, вытянутую или удлиненную форму размером в среднем $3 . .5 \mu \mathrm{m}$, в единичных случаях - до $10 \mu \mathrm{m}$. При визуальной оценке газовая составляющая в объеме включений не превышала $10 . .15 \%$, редко достигая $30 \%$.

В доломите газово-жидкие включения наблюдаются вдоль границ облачных центров и зон роста и параллельны поверхностям граней кристаллов. В кальците ГЖВ появляются в виде одиночных выделений, в группах или линейных следах, локализованных по плоскостям спайности и в трещинах. Доломиты содержат первичные, первично-вторичные и вторичные включения $[3,4]$, однако в работе изучались только первичные включения по происхождению.
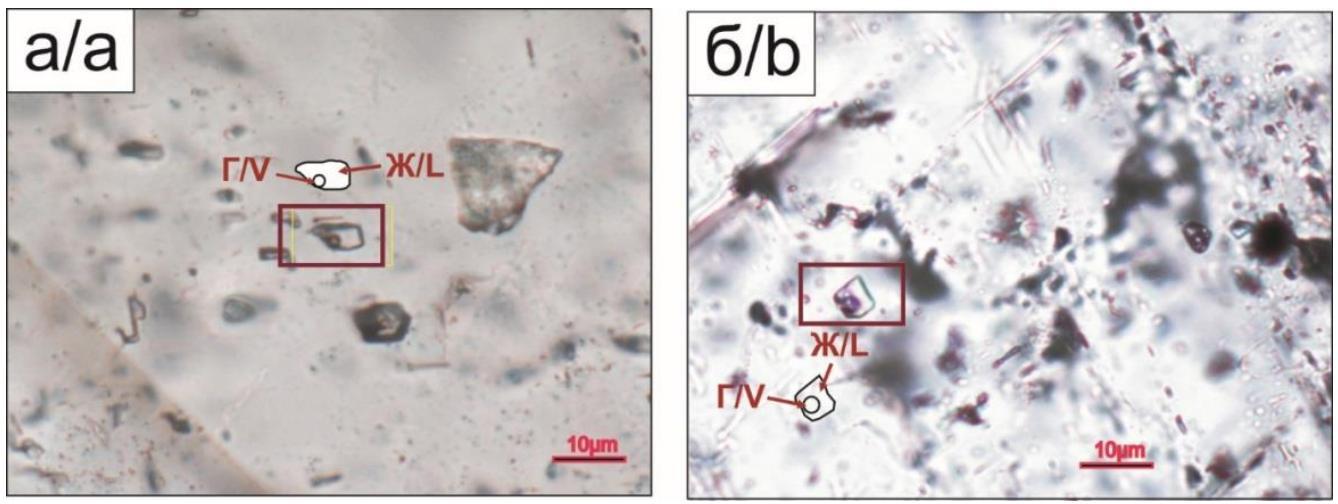

Pис. 3. Двухфазные газово-жидкие включения в кальиите (а) и доломите (б). Ж-жидкость; Г-газ

Fig. 3. Micrographs of biphasic primary fluid inclusions with a predominance of: a) fluid trapped along the calcite growth zone (in fractures); $b$ ) in dolomite. L-Liquid; $V$ - Vapor

\section{Микрокриотермометрия газово-жидких включений}

Определение температур фазовых переходов в газово-жидких включениях проводилось в кристаллических зернах доломита и в кальците, выполняющем прожилки и трещины карбонатных пород.

В кристаллах доломита полная гомогенизация включений осуществлялась в диапазоне температур 92,2-146 ${ }^{\circ} \mathrm{C}$ при среднем значении $115{ }^{\circ} \mathrm{C}$ (рис. 4).
Температура эвтектики варьирует от $-48,9$ до $-36,5^{\circ} \mathrm{C}$, что характеризует солевые системы составом растворов $\mathrm{CaCl}_{2}-\mathrm{H}_{2} \mathrm{O}$ и $\mathrm{MgCl}_{2} \pm \mathrm{KCl} \pm \mathrm{NaCl}-\mathrm{H}_{2} \mathrm{O}$. Температура плавления льда в ГЖВ доломитов составляет $-4,4 \ldots-1,3{ }^{\circ} \mathrm{C}$ и соответствует солености растворов 2,24...7,02 мас. \% экв. $\mathrm{NaCl}$ при среднем значении плотности флюидов 0,971 г/ $\mathrm{cm}^{3}$ (таблица). 
Таблица. Результаты крио- и термометрического изучения газово-жидких включений в кальците и доломите карбонатных пород Северо-Останинского месторождения

Table. Results of cryo- and thermometric study of fluid inclusions in calcite and dolomite of carbonate rocks of the North-Ostaninsk field

\begin{tabular}{|c|c|c|c|c|c|c|}
\hline \multirow{2}{*}{$\begin{array}{l}\text { Тип включений } \\
\text { Type of inclusions }\end{array}$} & $\mathrm{T}_{\text {гом }} / \mathrm{T}_{h}$ & $\mathrm{~T}_{\text {эв }} / \mathrm{T}_{i}$ & $\mathrm{~T}_{\text {пл. льда }} / \mathrm{T}_{m}$ & \multirow{2}{*}{$\begin{array}{c}C \text { солей, } \\
\text { мacc. \% экв- } \mathrm{NaCl} \\
\text { Eq. wt. \% } \mathrm{NaCl}\end{array}$} & \multirow{2}{*}{$\begin{array}{c}\rho, \\
\mathrm{g} / \mathrm{cm}^{3}\end{array}$} & \multirow{2}{*}{$\begin{array}{c}\text { Давление, } \\
\text { Bar } \\
\text { Pressure, Bar }\end{array}$} \\
\hline & \multicolumn{3}{|c|}{${ }^{\circ} \mathrm{C}$} & & & \\
\hline \multicolumn{7}{|c|}{ Доломит/Dolomite } \\
\hline \multirow{7}{*}{$Ж>\Gamma / \mathrm{V}>\mathrm{L}$} & 121,8 & $-48,8$ & $-1,3$ & 2,24 & 0,95754 & 4,56774 \\
\hline & 110,2 & $-36,5$ & $-2,6$ & 4,34 & 0,97588 & 4,85041 \\
\hline & 107,7 & -44 & $-2,1$ & 3,55 & 0,97336 & 4,9291 \\
\hline & 146 & $-48,9$ & $-4,4$ & 7,02 & 0,96726 & 4,74272 \\
\hline & 92,2 & $-36,9$ & - & - & & \\
\hline & 119 & -44 & $-2,8$ & 4,65 & 0,97208 & 4,6208 \\
\hline & 107.9 & $-38,8$ & $-3,3$ & 5,41 & 0,98279 & 4,92263 \\
\hline \multicolumn{7}{|c|}{ Кальцит/Calcite } \\
\hline \multirow{20}{*}{$Ж>\Gamma / \mathrm{V}>\mathrm{L}$} & 168 & -38 & $+1.2 \ldots+2$ & - & - & - \\
\hline & 130 & -35 & $-0,3 \ldots-0,8$ & 0,96 & 0,94464 & 4,48554 \\
\hline & 181.5 & -38 & $-0,3 \ldots-0,8$ & 0,96 & 0,89597 & 8,36426 \\
\hline & 246 & -42 & $-0,3 \ldots-0.8$ & 0,96 & 0,80674 & 33,1059 \\
\hline & 163 & -52 & $-3,9$ & 6,3 & 0,95011 & 5,84953 \\
\hline & 140.5 & - & $-0,4$ & 0,7 & 0,96692 & 4,58135 \\
\hline & 361 & -38 & $+0,3$ & - & - & - \\
\hline & 262,5 & $-35,1 \ldots-39,1$ & $-4,6 \ldots-0,1$ & 3,75 & 0,81233 & 44,7381 \\
\hline & 309 & -36 & $-1,4$ & 2,4 & 0,70623 & 92,8362 \\
\hline & 315 & $-27 ?$ & $-3,6$ & 5,9 & 0,74906 & 100,904 \\
\hline & 222 & -39 & $-0,3$ & 0,5 & 0,83947 & 20,4324 \\
\hline & 280 & -35 & $-3,1$ & 5,1 & 0,8003 & 60,0155 \\
\hline & 293 & $-37 \ldots-35 ?$ & $-0,2$ & 0,4 & 0,70934 & 73,5081 \\
\hline & 144 & $-37 \ldots-35 ?$ & $-0,2$ & 0,4 & 0,70934 & 4,67423 \\
\hline & 289 & - & - & - & - & - \\
\hline & 293 & - & - & - & - & - \\
\hline & 143 & - & - & - & - & - \\
\hline & 147 & - & $-1,8$ & 3,1 & 0,94337 & 4,78136 \\
\hline & 98 & - & $-1,1$ & 1,9 & 0,97105 & 5,26619 \\
\hline & 200 & - & - & - & - & - \\
\hline
\end{tabular}

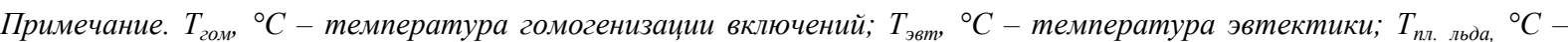
температура плавления льда; C солей, масс. \% экв. $\mathrm{NaCl}$ - концентрация солей, выраженная через масс. \% $\mathrm{NaCl}$ эквивалента; $\rho$ - плотность, $\mathrm{g} / \mathrm{cm}^{3}$; Ж>Г- двухфные газово-жидкие включения с преобладанием жсикой фазы, прочерк - не определено.

Note. $T_{h},{ }^{\circ} \mathrm{C}$-homogenization temperature of inclusions; $T_{i},{ }^{\circ} \mathrm{C}$-initial ice melting temperature (eutectic); $T_{m},{ }^{\circ} \mathrm{C}-m e l t i n g$ temperature of ice; Eq. wt. \% NaCl-salt concentration expressed in terms of wt. \% of the $\mathrm{NaCl}$ equivalent; $\rho$ - density, $\mathrm{g} / \mathrm{cm}^{3} ; V>L-t w o-p h a s e$ vapor-liquid inclusions with a predominance of the liquid phase; dash-not defined.

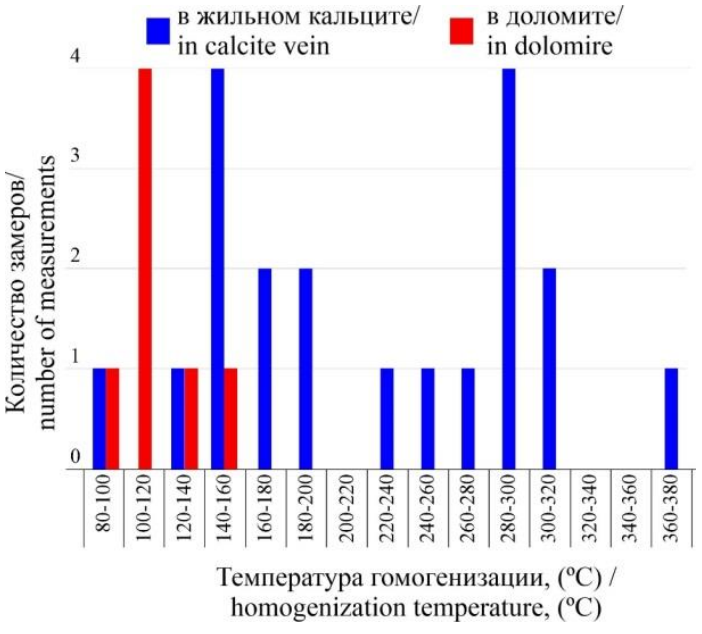

Pис. 4. Гистограмма зависимости распределения температур гомогенизачии от частоть встречаемости для жильного кальцита и доломита

Fig. 4. Histogram of homogenization temperature distribution and the frequency of occurrence for calcites vein and for dolomite
При расчёте солености раствора необходимо учитывать возможность присутствия растворенного метана, чтобы учесть незначительный эффект его растворения или сильный эффект от клатрата гидрата метана, имеющего тенденцию концентрировать соли в остаточном веществе жидкости [45]. Проведенные ранее работы по изучению газовой фазы в ГЖВ доломитов показали отсутствие метана [36], поэтому полученные значения солености являются максимальными.

Анализ газово-жидких включений в жильном кальците показал широкий спектр температур гомогенизации в пределах $98-361{ }^{\circ} \mathrm{C}$, которые разбиваются на группы с пиками интервалов $140 \ldots 160{ }^{\circ} \mathrm{C}$ и $280 \ldots 300{ }^{\circ} \mathrm{C}$ (рис. 4). Состав растворов двухфазовых включений отвечает солевым системам $\mathrm{MgCl}_{2} \pm \mathrm{NaCl} \pm \mathrm{KCl}-\mathrm{H}_{2} \mathrm{O}$ (температура эвтектики около -35 и $-38{ }^{\circ} \mathrm{C}$ ), либо растворы могут содержать преимущественно $\mathrm{CaCl}_{2}$ с примесями $\mathrm{MgCl}_{2}$ в системе $\mathrm{CaCl}_{2} \pm \mathrm{MgCl}_{2}-\mathrm{H}_{2} \mathrm{O}$ (температура эвтектики около -42 и $\left.-52{ }^{\circ} \mathrm{C}\right)$. 
Температура плавления льда, измеренная во включениях кальцита, дает значения от +2 до $-4,6^{\circ} \mathrm{C}$, соответственно, минерализация раствора в пересчете на экв. $\mathrm{NaCl}$ составляет $0,4 \ldots 6,3 \%$, а плотность фиксируется в пределах $0,706 \ldots 0,971$ г/ $\mathrm{cm}^{3}$ (таблица).

На рис. 5 приведен график зависимости солености флюида от температуры гомогенизации для доломита и кальцита. График показывает, что доломитизация известняков могла происходить из растворов, образующихся в результате смешения метеорных и морских вод, при этом среднее значение солености морской воды составляет 3,5 мас. \% экв. $\mathrm{NaCl}$. Учитывая, что рассчитанные средние показатели солености доломитообразующих растворов достигают 4,5 \% экв. $\mathrm{NaCl}$, наличие жидкостей с низкой минерализацией $<5 \% \mathrm{NaCl}$ (мас. \% экв. $\mathrm{NaCl}$ ) свидетельствует о более активном участии метеорной воды в процессе минерализации и образования доломита в первичной известковой матрице пород [45]. Кроме того, при вероятном воздействии высокоминерализованных растворов на известняки можно было ожидать появление в образцах сульфатов, например, гипса или ангидрита, однако в изучаемых породах отмеченные минералы не наблюдаются.

С другой стороны, флюиды, из которых шло выделение кальцита в прожилках и трещинах известняков, относятся к высокотемпературным флюидам. Температурный режим при формировании кальцита фиксирует скачкообразное изменение от 98 до $315^{\circ} \mathrm{C}$ и в единичных случаях до $361{ }^{\circ} \mathrm{C}$, что позволяет предположить участие нагретых гидротермальных растворов.

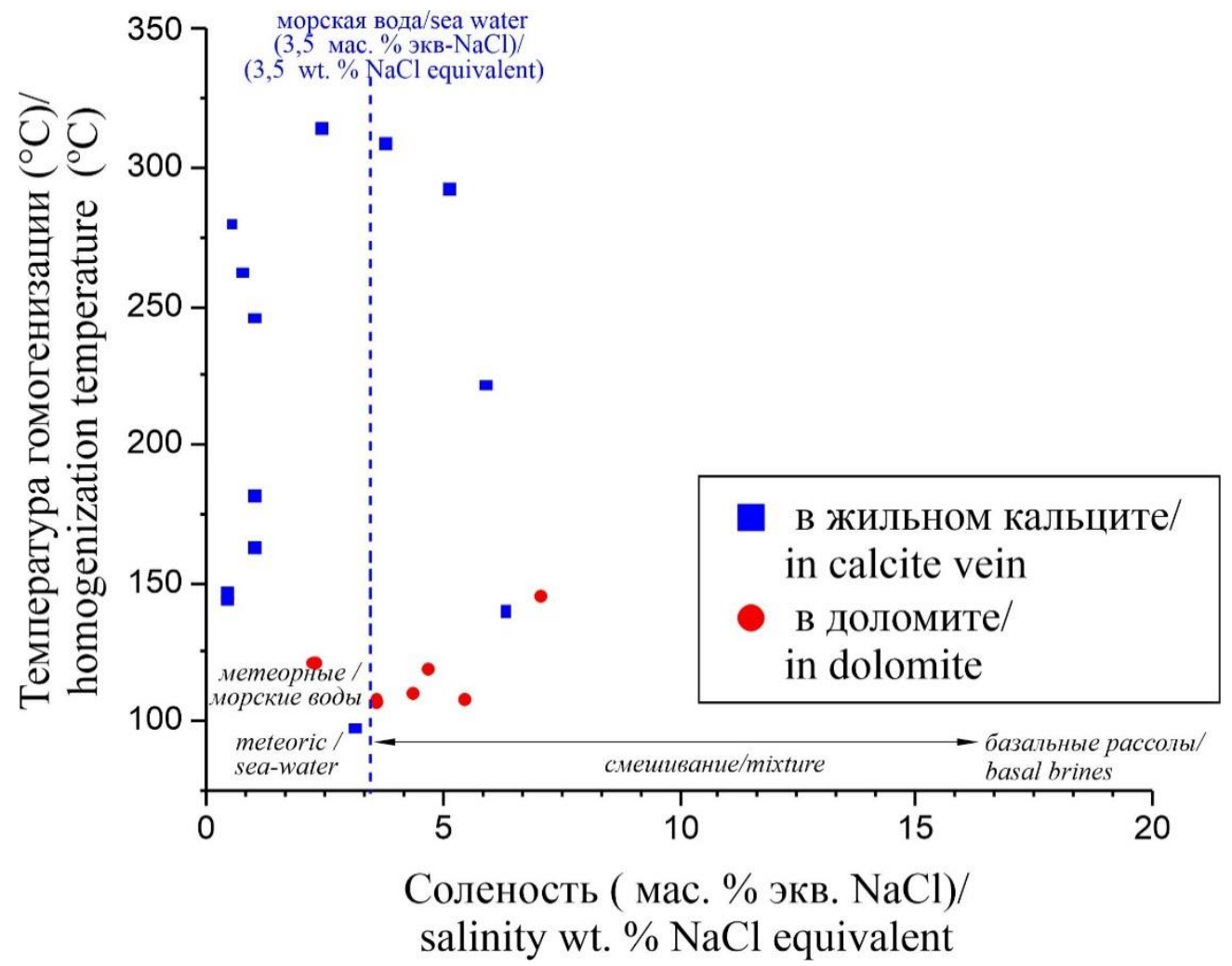

Pис. 5. Расположение фигуративных точек минерализованных флюидов из газово-жидких включений в доломите и кальичте на графике зависимости солености и температуры гомогенизации по [46]

Fig. 5. Location of figurative points of mineralized fluids from fluid inclusions in dolomite and calcite on the graph salinity vs. homogeneous temperature [46]

\section{Заключение}

Петрографические и микротермометрические данные показывают наличие двухфазных (жидкость + газ) флюидных включений во вторичных карбонатных минералах пород - доломите и кальците. Первый образует правильные и частично правильные кристаллы в виде ромбоэдров, которые замещают органогеннообломочные известняки, второй выполняет разнонаправленные трещины в породах или образует пятнистые обособления в образцах.

Образование коллекторов на месторождении связывают с развитием доломита по известнякам вплоть до полного их замещения. В этом случае фиксируется поровое пространство между ромбоэдрами доломита либо области выщелачивания в породах, часто с битумоидами. На основании микротермометрических данных включений в доломите установлено, что образование минерала шло из растворов низкой солености (в среднем 4,5 мас. \% экв. $\mathrm{NaCl}$ ) и при относительно умеренной температуре (средняя температура гомогенизации $110 \ldots 120^{\circ} \mathrm{C}$ ). Таким источником могли являться метеорно- смешанные воды, на что указывает некоторое опреснение доломитизирующих растворов. Принимая во внимания то, что образование доломитов носит площадное развитие только в тех скважинах на Северо-Останинском месторожде- 
нии, где имеется выход органогенной постройки на эрозионную поверхность фундамента, включая изученные скв. X и X1, предполагаемый механизм образования флюидов, приводящий к доломитизации известняков, в результате смешения метеорных вод,

\section{СПИСОК ЛИТЕРАТУРЫ}

1. Goldstein R.H. Fluid inclusions in sedimentary and diagenetic systems // Lithos. - 2001. - V. 55. - № 1-4. - P. 159-193.

2. Characteristics of fluid inclusions and implications for the timing of hydrocarbon accumulation in the cretaceous reservoirs, Kelasu Thrust Belt, Tarim Basin, China / S. Zhao, W. Chen, L. Zhou, P. Zhou, J. Zhang // Marine and Petroleum Geology. - 2019. V. 99. - P. 473-487. DOI: 10.1016/j.marpetgeo.2018.10.041

3. Roedder E. Fluid inclusions // Reviews in Mineralogy. -USA Mineralogical Society of America, 1984. - V. 12. - 644 p.

4. Goldstein R., Reynolds J. Systematics of fluid inclusions in diagenetic minerals. Short Course № 31. - Tulsa, Oklahoma: Society for Sedimentary Geology (SEPM), 1994. - 199 p. DOI: $10.2110 /$ scn. 94.31

5. Petroleum type determination through homogenization temperature and vapour volume fraction measurements in fluid inclusions / J. Bourdet, J. Pironon, G. Levresse, J. Tritlla // Geofluids. - 2008. - V. 8. - № 1. - P. 46-59. DOI: $10.1111 / j .1468-8123.2007 .00204 . x$

6. Chemical changes of fluid inclusion oil trapped during the evolution of an oil reservoir: Jabiru-1A case study (Timor Sea, Australia) / J. Bourdet, P. Eadington, H. Volk, S.C. George, J. Pironon, R. Kempton // Marine and Petroleum Geology 2012. - V. 36. - № 1. - P. 118-139. DOI: 10.1016/j.marpetgeo. 2012.05.006

7. Origin of the saline paleofluids in fault-damage zones of the Jabal Qusaybah Anticline (Adam Foothills, Oman): constraints from fluid inclusions geo- chemistry / M. Mozafari, R. Swennen, P. Muchez, E. Vassilieva, F. Balsamo, F. Storti, J. Pironon, C. Taberner // Marine and Petroleum Geology. - 2017. - V. 86. P. 537-546. DOI: 10.1016/j.marpetgeo.2017.06.010

8. McLimans R.K. The application of fluid inclusions to migration of oil and diagenesis in petroleum reservoirs // Applied Geochemistry. 1987. - V. 2. - P. 585-603.

9. Lisk M., O'Brien G.W., Eadington P.J. Quantitative evaluation of the oil-leg potential in the Oliver gas field, Timor Sea, Australia // AAPG (American Association of Petroleum Geologists) Bulletin. 2002. - V. 86. - P. 1531-1542.

10. Tseng H.Y., Pottorf R.J. Fluid inclusion constraints on petroleum PVT and com- positional history of the Greater Alwyn-South Brent petroleum system, northern North Sean // Marine and Petroleum Geology. - 2002. - V. 19. - P. 797-809.

11. Tseng H.Y., Pottorf R.J. The application of fluid inclusion PVT analysis to studies of petroleum migration and reservoirs // Journa of Geochemical Exploration. - 2002. - V. 78-79. - P. 433-436.

12. Parnell J. Potential of palaeofluid analysis for understanding oil charge history // Geofluids. - 2010. - V. 10. - P. 73-82.

13. Fluid inclusion and microfabric studies on Zechstein carbonates (Ca2) and related fracture mineralizations - new insights on gas migration in the Lower Saxony Basin (Germany) / F. Duschl, A.V.D. Kerkhof, G. Sosa, B. Leiss, B. Wiegand, A. Vollbrecht, M. Sauter // Marine and Petroleum Geology. - 2016. - V. 77. P. 300-322. DOI: 10.1016/j.marpetgeo.2016.06.020

14. Hydrocarbon composition of authigenic inclusions - applications to elucidation of petroleum reservoir filling history / D.A. Karlsen, T. Nedkvitne, S.R. Larte, K. Bjorlykke // Geochimica et Cosmochimica Acta - 1993 - V. 57 - P. 3641-3659.

15. Characterisation of the molecular composition of included petroleum / D.M. Jones, G. Macleod, S.R. Larter, D.L. Hall, A.C. Aplin, M. Chen // Proceedings of the Sixth Biennial PanAmerican Conference on Research on Fluid Inclusions (PACROF VI) / Eds. P.E. Brown, S.G. Hagemann. - Madison, Wisconsin, USA, 1996. - P. 64-65.

16. Mapping hydrocarbon charge histories: detailed characterisation of the South Pepper Oil Field, Carnarvon Basin / M. Lisk, просачивающихся с поверхности, и нагретых гидротермальных растворов, позволяет это объяснить.

Источником флюидов, из которых минерализуются кальцитом трещины и прожилки карбонатных пород, являются нагретые гидротермальные воды, достигающие температуры до $360{ }^{\circ} \mathrm{C}$.

S.C. George, R.E. Summons, R.A. Quezada, G.W. OBrien // APPEA Journal. - 1996. - V. 36. - P. 445-463.

17. Isaksen G., Pottorf R.J., Jenssen A. I. Correlation of fluid inclusions and reservoir oils to infer trap fill history in the South Viking Graben, North Sea // Petroleum Geoscience. - 1998. V. 4. - P. 41-55

18. Combined use of confocal laser scanning microscopy and PVT simulation for estimating the composition and physical properties of petroleum in fluid inclusions / A.C. Aplin, G. Macleod, S.R. Larter, K.S. Pedersen, H. Sorensen, T. Booth // Marine and Petroleum Geology. - 1999. - V. 16. - P. 97-110. DOI: 10.1016/S0264-8172(98)00079-8

19. Depositional, diagenetic, thermal, and maturation histories of Cretaceous Mishrif Formation, Fateh Field, Dubai / P.E. Videtich, R.K. McLimans, H.K.S. Watson, R.M. Nagy // American Association of Petroleum Geologists Bulletin. - 1988. - V. 72. P. 1143-1159.

20. Paleofluid-flow circulation within a Triassic rift basin: evidence from oil inclusions and thermal histories / H.Y. Tseng, R.C. Burruss, T.C. Onstott, G. Omar // Geological Society of America Bulletin. - 1999. - V. 111. - P. 275-290.

21. Petroleum inclusions and residual oils: constraints for deciphering petroleum migration / H. Volk, U. Mann, O. Burde, B. Horsfield, V. Suchý // Journal of Geochemical Exploration. - 2000. V. 71. - P. 307-311. DOI: 10.1016/S0375-6742(00)00156-4

22. The use of integrated fluid inclusion studies in constraining oil charge history and reservoir compartmentation: examples from the Jeanne d'Arc Basin, offshore Newfoundland / J. Parnell, D. Middleton, H.H. Chen, D. Hall // Marine and Petroleum Geology. - 2001. - V. 18. - P. 535-549.

23. Liu K., Eadington P. Quantitative fluorescence techniques for detecting residual oils and reconstructing hydrocarbon charge history // Organic Geochemistry. - 2005 - V. 36. - P. 1023-1036. DOI: $10.1016 /$ j.orggeochem.2005.02.008

24. Constraints of fluid inclusions and $\mathrm{C}, \mathrm{O}$ isotopic compositions on the origin of the dolomites in the Xisha Islands, South China Sea / D. Bi, S. Zhai, D. Zhang, X. Liu, X. Liu, L. Jiang // Chemical Geology. - 2018. - V. 493. - P. 504-517. DOI: 10.1016/j.chemgeo.2018.07.005

25. Conliffe J. Geological setting and genesis of high-grade iron ore deposits in the Eastern Labrador trough, Newfoundland and Labrador // Atlantic Geology. - 2015. - V. 55. - № 1. - P. 1-25.

26. Burial and hydrothermal diagenesis of Ordovician carbonates from the Michigan Basin, Ontario, Canada / M. Coniglio, R. Sherlock, A.E. Williams-Jones, K. Middleton, S.K. Frape // Dolomites. A Volume in Honour of Dolomieu / Eds. B.H. Purser, M.E. Tucker, D.H. Zenger. - Cambridge: International Association of Sedimentologists. Special Publication, 1994. V. 21. - P. 231-254.

27. Wojcik K.M., Goldstein R.H., Andwalton A.W. History of diagenetic fluids in a distant foreland area, Middle and Upper Pennsylvanian, Cherokee basin, Kansas, USA: Fluid inclusion evidence // Geochimica et Cosmochimica Acta. - 1994. - V. 58. P. $1175-1191$

28. High-temperature dolomite in the Lower Cretaceous Cupido Formation, Bustamante Canyon, northeast Mexico: Petrologic, geochemical and microthermometric constraints / G.S. GuzzyArredondo, G. Murillo-Muñetón, D.J. Morán-Zenteno, J.M. Grajales-Nishimura, R. Martínez-Ibarra, P. Schaaf // Revista Mexicana de Ciencias Geologicas. - 2007. - V. 24. - № 2. P. 131-149.

29. Diagenesis in Mesozoic carbonate rocks in the North Pyrénées (France) from mineralogy and fluid inclusion analysis: example of Rousse reservoir and caprock / S. Renard, J. Pironon, J. Sterpenich, C. Carpentier, M. Lescanne, E.C. Gaucher // Chemical Geology. 2019. - V. 508. - P. 3-46. DOI: 10.1016/j.chemgeo.2018.06.017 
30. Discussion of multiple formation mechanisms of saddle dolomites comparison of geochemical data of Proterozoic-Paleozoic dolomites / B. Peng, G. Li, Z. Li, C. Liu, Y. Zuo, W. Zhang, C. Yao // Energy Exploration and Exploitation. - 2018. - V. 36. № 1. - P. 66-96. DOI: 10.1177/0144598717728464

31. Samani P.N., Mirshahani M., Khodaei N. Petrographic characteristics and fluid inclusion study of carbonate cements in Permian-Triassic rock sequence of Southern Iran: an implication of rock-fluid interactions in Carbonate Reservoir Rocks // Journal of Petroleum Science and Technology. - 2017. - V. 7. - № 3. P. 117-134.

32. Chen D., Qing H., Yang C. Multistage hydrothermal dolomites in the Middle Devonian (Givetian) carbonates from the Guilin area, South China // Sedimentology. - 2004. - V. 51. - № 5. - P. 1029-1051. DOI: 10.1111/j.1365-3091.2004.00659.x

33. Месторождение Северо-Останинское. НефтьГазИнфом. Независимый нефтегазовый Портал. URL: http://oilgasinform.ru/ science/fields/severoostaninskoe (дата обращения: 12.02.2020).

34. Белов Р.В. Переинтерпретация сейсморазведочных материалов по верхнепалеозойским залежам УВ юго-востока Западной Сибири // Геология нефти и газа. - 1992. - V. 4. - С. 5-8. URL: http://geolib.ru/OilGasGeo/1992/04/Stat/stat02.html (дата обращения 19.03.2020).

35. Конторович А.Э. Первая отраслевая научноисследовательская организация в области геологии нефти и газа в Сибири // Геология и минерально-сырьевые ресурсы Сибири. - Новосибирск: СНИИГГиМС, 2012. - № 1. - С. 5-15.

36. Краснощекова Л.А., Гарсия А.С., Белозёров В.Б. Состав флюидных включений по КР-спектрам в палеозойских карбонатных породах Северо-Останинского месторождения, Западная Сибирь // Известия Томского политехнического университета. 2019. - T. 330. - № 3. - C. 187-203. DOI: 10.18799/24131830/ 2019/3/178

37. Белозёров В.Б., Гарсия А.С. Перспективы поиска залежей нефти в отложениях девона юго-восточной части Западно-
Сибирской плиты // Известия Томского политехнического университета. - 2018. - Т. 329. - № 6. - С. 128-139.

38. Geofluids developments in microthermometry / V. Hurai, M. Hurainova, M. Slobodni, R. Thomas. - Amsterdam: Elsevier, 2015. $-489 \mathrm{p}$.

39. Рёддер Э. Флюидные включения в минералах. В 2-х т. Т. 2: Использование включений при изучении генезиса пород и руд / Пер. с англ. - М.: Мир, 1987. - Т. 2. - 632 с.

40. Shepherd T.J., Rankin A.H., Alderton D.H.M. A practical guide to fluid inclusions. - Glasgow and London: Blackie, 1985. - 239 c.

41. Борисенко А.С. Изучение солевого состава газово-жидких включений в минералах методом криометрии // Геология и геофизика. - 1977. - № 8. - С. 16-27.

42. Bodnar R.J. Revised equation and table for determining the freezing point depression of $\mathrm{H} 2 \mathrm{O}-\mathrm{NaCl}$ solutions // Geochimica et Cosmochimica Acta. - 1993. - V. 57. - № 3. - P. 683-684.

43. Zhang Y., Frantz J.D. Determination of the homogenization temperatures and densities of supercritical fluids in the system $\mathrm{NaCl}-\mathrm{KCl}-\mathrm{CaCl} 2-\mathrm{H} 2 \mathrm{O}$ using synthetic fluid inclusions // Chemical Geology. - 1987. - V. 64. - P. 335-350.

44. Bakker R.J. Package FLUIDS 1. Computer programs for analysis of fluid inclusion data and for modelling bulk fluid properties // Chemical Geology. - 2003. - V. 194. - № 1-3. - P. 3-23. DOI: 10.1016/S0009-2541(02)00268-1

45. Origin of Lower Ordovician dolomites in eastern Laurentia: controls on porosity and implications from geochemistry / E. Azomani, K. Azmy, N. Blamey, U. Brand, I. Al-Aasm // Marine and Petroleum Geology. - 2013. - V. 40. - № 1. - P. 99-114. DOI: 10.1016/j.marpetgeo.2012.10.007

46. Bodnar R.J. Hydrothermal solutions // Encyclopedia of geochemistry / Eds. C.P. Marshall, R.W. Fairbridge. - Lancaster: Kluwer Academic Publishers, 1999. - P. 333-337.

Поступила 05.08.2020 г.

\section{Информация об авторах}

Краснощекова Л.А., кандидат геолого-минералогических наук, доцент отделения геологии Инженерной школы природных ресурсов, Национальный исследовательский Томский политехнический университет.

Гарсия Бальса A.C., аспирант Инженерной школы природных ресурсов, Национальный исследовательский Томский политехнический университет.

Белозёров В.Б., доктор геолого-минералогических наук, заведующий лабораторией геологии Центра подготовки и переподготовки специалистов нефтегазового дела Инженерной школы природных ресурсов, Национальный исследовательский Томский политехнический университет. 
UDC 552.54: 552.14: 553.08

\title{
CONDITIONS FOR FORMATION OF SECONDARY DOLOMITES IN PALEOZOIC CARBONATE RESERVOIRS OF NORTH-OSTANINSK FIELD (WESTERN SIBERIA) ACCORDING TO MICROCRYOTHERMOMETRIC DATA
}

\author{
Lyubov A. Krasnoshchekova1, \\ krasnl@tpu.ru
}

\author{
Aura S. Garcia', \\ garciaas@hw.tpu.ru \\ Vladimir B. Belozerov' 1 , \\ belozerovvb@hw.tpu.ru \\ 1 National Research Tomsk Polytechnic University, \\ 30, Lenin avenue, Tomsk, 634050, Russia.
}

\begin{abstract}
The relevance of the research is determited by the development of new exploration strategies related to the non-anticlinal hydrocarbon deposits of the Paleozoic basement complex that is caused by the low efficiency of exploration activities carried out within traditional exploration structures. Given the significant decrease in oil-promising structures that provide an increase in hydrocarbon reserves from platform cover deposits, the identification of «non-structural» prospecting objects in the basement rocks based on a new understanding of the formation of Paleozoic carbonate reservoirs will contribute to the further development of the oil and gas industry in Western Siberia.

The aim of the research is the analysis of new data from fluid inclusions of Middle-Devonian dolomites of the North-Ostaninsk field in order to study the mechanism of dolomitization of organogenic and bioclastic limestones, which are the main oil-promising object of the Paleozoic complex within the Nyurolskaya basin

The research object is the carbonate bioherm from two wells at the roof part of the Paleozoic basement (horizon M1) of the NorthOstaninsk oil and gas condensate field. In the studied wells, the organogenic structure reaches the erosive surface of the basement and the roof part of the limestones, which are intensely dolomitized.

Results. The formation of reservoirs of the North-Ostaninsk field is associated with secondary dolomitization of organogenic and bioclastic limestones related to the bioherm construction of the Paleozoic - horizon M1. Cryo- and thermometrical studies on two-phase primary fluid inclusion in dolomite crystals allowed determining the average homogenization temperature of $110-120{ }^{\circ} \mathrm{C}$ and an average salinity of $4,5 \mathrm{wt}$. \% NaCl equivalent, which may indicate the formation of dolomites from moderate-temperature solutions of low salinity, formed as a result of a mixing of meteoric water and hydrothermal sources seeping from the surface along the fault system. The latter draining the weathering crust of volcanic rocks, saturate the water with magnesium and iron and contribute to the dolomitization of carbonate rocks.
\end{abstract}

\section{Key words:}

Microthermometry, cryothermometry, fluid inclusions, Pre-Jurassic carbonate rocks, dolomite, Western Siberia.

\section{REFERENCES}

1. Goldstein R.H. Fluid inclusions in sedimentary and diagenetic systems. Lithos, 2001, vol. 55, no. 1-4, pp. 159-193.

2. Zhao S., Chen W., Zhou L., Zhou P., Zhang J. Characteristics of fluid inclusions and implications for the timing of hydrocarbon accumulation in the cretaceous reservoirs, Kelasu Thrust Belt, Tarim Basin, China. Marine and Petroleum Geology, 2019, vol. 99, pp. 473-487. DOI: 10.1016/j.marpetgeo.2018.10.041

3. Roedder E. Fluid inclusions. Reviews in Mineralogy. USA, Mineralogical Society of America, 1984. Vol. 12.644 p.

4. Goldstein R., Reynolds J. Systematics of fluid inclusions in diagenetic minerals. Short Course № 31. Tulsa, Oklahoma, Society for Sedimentary Geology (SEPM), 1994.199 p. DOI: 10.2110/scn.94.31

5. Bourdet J., Pironon J., Levresse G., Tritlla J. Petroleum type determination through homogenization temperature and vapour volume fraction measurements in fluid inclusions. Geofluids, 2008, vol. 8, no. 1, pp. 46-59. DOI: 10.1111/j.1468-8123.2007.00204.x

6. Bourdet J., Eadington P., Volk H., George S.C., Pironon J., Kempton R. Chemical changes of fluid inclusion oil trapped during the evolution of an oil reservoir: Jabiru-1A case study (Timor Sea, Australia). Marine and Petroleum Geology, 2012, vol. 36, no. 1, pp. 118-139. DOI: 10.1016/j.marpetgeo.2012.05.006

7. Mozafari M., Swennen R., Muchez P., Vassilieva E., Balsamo F., Storti F., Pironon J., Taberner C. Origin of the saline paleofluids in fault-damage zones of the Jabal Qusaybah Anticline (Adam Foothills, Oman): constraints from fluid inclusions geo- chemistry. Marine and Petroleum Geology, 2017, vol. 86, pp. 537-546. DOI: 10.1016/j.marpetgeo.2017.06.010
8. McLimans R.K. The application of fluid inclusions to migration of oil and diagenesis in petroleum reservoirs. Applied Geochemistry, 1987, vol. 2, pp. 585-603.

9. Lisk M., O'Brien G.W., Eadington P.J. Quantitative evaluation of the oil-leg potential in the Oliver gas field, Timor Sea, Australia. AAPG (American Association of Petroleum Geologists) Bulletin, 2002, vol. 86, pp. 1531-1542.

10. Tseng H.Y., Pottorf R.J. Fluid inclusion constraints on petroleum PVT and com- positional history of the Greater Alwyn-South Brent petroleum system, northern North Sea. Marine and Petroleum Geology, 2002, vol. 19, pp. 797-809.

11. Tseng H.Y., Pottorf R.J. The application of fluid inclusion PVT analysis to studies of petroleum migration and reservoirs. Journal of Geochemical Exploration, 2003, vol. 78-79, pp. 433-436.

12. Parnell J. Potential of palaeofluid analysis for understanding oil charge history. Geofluids, 2010, vol. 10, pp. 73-82.

13. Duschl F., Kerkhof A.V.D., Sosa G., Leiss B., Wiegand B., Vollbrecht A., Sauter M. Fluid inclusion and microfabric studies on Zechstein carbonates $(\mathrm{Ca} 2)$ and related fracture mineralizations new insights on gas migration in the Lower Saxony Basin (Germany). Marine and Petroleum Geology, 2016, vol. 77, pp. 300-322. DOI: 10.1016/j.marpetgeo.2016.06.020

14. Karlsen D.A., Nedkvitne T., Larter S.R., Bjorlykke K. Hydrocarbon composition of authigenic inclusions - applications to elucidation of petroleum reservoir filling history. Geochimica et Cosmochimica Acta, 1993, vol. 57, pp. 3641-3659.

15. Jones D.M., Macleod G., Larter S.R., Hall D.L., Aplin A.C., Chen M. Characterisation of the molecular composition of included petroleum. Proceedings of the Sixth Biennial Pan-American Conference 
on Research on Fluid Inclusions (PACROFI VI). Eds. P.E. Brown, S.G. Hagemann. Madison, Wisconsin, USA, 1996. pp. 64-65.

16. Lisk M., George S.C., Summons R.E., Quezada R.A., OBrien G.W Mapping hydrocarbon charge histories: detailed characterisation of the South Pepper Oil Field, Carnarvon Basin. APPEA Journal, 1996, vol. 36, pp. 445-463.

17. Isaksen G., Pottorf R.J., Jenssen A.I. Correlation of fluid inclusions and reservoiredoils to infer trap fill history in the South Viking Graben, North Sea. Petroleum Geoscience, 1998, vol. 4, pp. 41-55.

18. Aplin A.C., Macleod G., Larter S.R., Pedersen K.S., Sorensen H., Booth T. Combined use of confocal laser scanning microscopy and PVT simulation for estimating the composition and physical properties of petroleum in fluid inclusions. Marine and Petroleum Geology, 1999, vol. 16, pp. 97-110. DOI: 10.1016/S0264-8172(98)00079-8

19. Videtich P.E., McLimans R.K., Watson H.K.S. Nagy, R.M. Depositional, diagenetic, thermal, and maturation his- tories of Cretaceous Mishrif Formation, Fateh Field, Dubai. American Association of Petroleum Geologists Bulletin, 1988, vol. 72, pp. 1143-1159.

20. Tseng H.Y., Burruss R.C., Onstott T.C., Omar G. Paleofluid-flow circulation within a Triassic rift basin: evidence from oil inclusions and thermal histories. Geological Society of America Bulletin 1999, vol. 111, pp. 275-290

21. Volk H., Mann U., Burde O., Horsfield B., Suchý V. Petroleum inclusions and residual oils: constraints for deciphering petroleum migration Journal of Geochemical Exploration, 2000, vol. 71, pp. 307-311. DOI: 10.1016/S0375-6742(00)00156-4

22. Parnell J., Middleton D., Chen H.H., Hall D. The use of integrated fluid inclusion studies in constraining oil charge history and reservoir compartmentation: examples from the Jeanne d'Arc Basin, offshore Newfoundland. Marine and Petroleum Geology, 2001, vol. 18 , pp. 535-549.

23. Liu K., Eadington P. Quantitative fluorescence techniques for detecting residual oils and reconstructing hydrocarbon charge history. Organic Geochemistry, 2005, vol. 36, pp. 1023-1036. DOI 10.1016/j.orggeochem.2005.02.008

24. Bi D., Zhai S., Zhang D., Liu X., Liu X., Jiang L. Constraints of fluid inclusions and $\mathrm{C}, \mathrm{O}$ isotopic compositions on the origin of the dolomites in the Xisha Islands, South China Sea. Chemical Geology, 2018, vol. 493, pp. 504-517. DOI: 10.1016/j.chemgeo.2018.07.005

25. Conliffe J. Geological setting and genesis of high-grade iron ore deposits in the Eastern Labrador trough, Newfoundland and Labrador. Atlantic Geology, 2015, vol. 55, no. 1, pp. 1-25.

26. Coniglio M., Sherlock R., Williams-Jones A.E., Middleton K., Frape S.K. Burial and hydrothermal diagenesis of Ordovician carbonates from the Michigan Basin, Ontario, Canada. Dolomites - A Volume in Honour of Dolomieu. Eds. B.H. Purser, M.E. Tucker, D.H. Zenger. Cambridge, International Association of Sedimentologists. Special Publication, 1994, vol. 21, pp. 231-254.

27. Wojcik K.M., Goldstein R.H., Andwalton A.W. History of diagenetic fluids in a distant foreland area, Middle and Upper Pennsylvanian, Cherokee basin, Kansas, USA: fluid inclusion evidence. Geochimica et Cosmochimica Acta, 1994, vol. 58, pp. 1175-1191.

28. Guzzy-Arredondo G.S., Murillo-Muñetón G., Morán-Zenteno D.J. Grajales-Nishimura J.M., Martínez-Ibarra R., Schaaf P. Hightemperature dolomite in the Lower Cretaceous Cupido Formation, Bustamante Canyon, northeast Mexico: petrologic, geochemical and microthermometric constraints. Revista Mexicana de Ciencias Geologicas, 2007, vol. 24, no. 2, pp. 131-149

29. Renard S., Pironon J., Sterpenich J., Carpentier C., Lescanne M., Gaucher E.C. Diagenesis in Mesozoic carbonate rocks in the North Pyrénées (France) from mineralogy and fluid inclusion analysis: Example of Rousse reservoir and caprock. Chemical Geology, 2019, vol. 508, pp. 30-46. DOI: 10.1016/j.chemgeo.2018.06.017

30. Peng B., Li G., Li Z., Liu C., Zuo Y., Zhang W., Yao C. Discussion of multiple formation mechanisms of saddle dolomites comparison of geochemical data of Proterozoic-Paleozoic dolomites. Energy Exploration and Exploitation, 2018, vol. 36, no. 1, pp. 66-96. DOI: $10.1177 / 0144598717728464$
31. Samani P.N., Mirshahani M., Khodaei N. Petrographic characteristics and fluid inclusion study of carbonate cements in PermianTriassic Rock Sequence of Southern Iran: an implication of rockfluid interactions in carbonate reservoir rocks. Journal of Petroleum Science and Technology, 2017, vol. 7, no. 3, pp. 117-134.

32. Chen D., Qing H., Yang C. Multistage hydrothermal dolomites in the Middle Devonian (Givetian) carbonates from the Guilin area, South China. Sedimentology, 2004, vol. 51, no. 5, pp. 1029-1051. DOI: 10.1111/j.1365-3091.2004.00659.x

33. Mestorozhdenie Severo-Ostaninskoe [Severo-Ostaninskoe deposit] Neft'GazInfom. Available at: http://oilgasinform.ru/science/fields/ severoostaninskoe (accessed 12 February 2020).

34. Belov R.V. Reinterpretation of seismic data on Upper Paleozoic hydrocarbon deposits in the southeastern part of Western Siberia. Oil and gas geology, 1992, vol. 4, pp. 5-8. In Rus. Available at: http://geolib.ru/ OilGasGeo/1992/04/Stat/stat02.html (accessed 19 March 2020).

35. Kontorovich V.A. Pervaya otraslevaya nauchno-issledovatelskaya organizatsiya v oblasti geologii nefti i gaza v Sibiri [The first department research organization in the field of geology of oil and gas in Siberia]. Geologiya i mineralno-syrevye resursy Sibiri [Geology and mineral resources of Siberia]. Novosibirsk, SNIIGGIMS Publ., 2012. No. 1, pp. 5-15.

36. Krasnoshchekova L., Garcia A., Belozerov V. Composition of fluid inclusions by Raman spectroscopy in Paleozoic carbonate rocks of Severo-Ostaninsk field, Western Siberia. Bulletin of the Tomsk Polytechnic University. Geo Assets Engineering, 2019, vol. 330, no. 3, pp. 187-203. DOI: 10.18799/24131830/2019/3/178

37. Belozerov V., Garcia Aura S. Prospects of searching for oil reservoirs in the Devonian deposits of the south-eastern part of the Western-Siberian plate. Bulletin of the Tomsk Polytechnic University. Geo Assets Engineering, 2018, vol. 329, no. 6, pp. 128-139. Available at: http://izvestiya.tpu.ru/archive/article/view/2052 (accessed 09 February 2019).

38. Hurai V., Hurainova M., Slobodni, M., Thomas R. Geofluids developments in Microthermometry. Amsterdam, Elsevier, 2015. 489 p.

39. Roedder E. Flyuidnye vklyucheniya v mineralakh [Fluid inclusions in minerals]. Ispolzovanie vklyucheniy pri izuchenii genezisa porod $i$ rud [Use of inclusions when studying genesis of rocks and ores]. Translated from English. Moscow, Mir Publ., 1987. Vol. 2, 632 p.

40. Shepherd T.J., Rankin A.H., Alderton D.H.M. A practical guide to fluid inclusions. Glasgow; London, Blackie, 1985. 239 p.

41. Borisenko A.S. Izuchenie solevogo sostava gazovo-zhidkikh vklyucheniy v mineralakh metodom kriometrii [Study of salt composition of gas-liquid inclusions in minerals by method of cryometry]. Sovietskaya Geologiya Geophysics, 1977, no. 8, pp. 16-27.

42. Bodnar R.J. Revised equation and table for determining the freezing point depression of $\mathrm{H}_{2} \mathrm{O}-\mathrm{NaCl}$ solutions. Geochimica et Cosmochimica Acta, 1993, vol. 57, no. 3, pp. 683-684.

43. Zhang Y., Frantz J.D. Determination of the homogenization temperatures and densities of supercritical fluids in the system $\mathrm{NaCl}-$ $\mathrm{KCl}-\mathrm{CaCl}_{2}-\mathrm{H}_{2} \mathrm{O}$ using synthetic fluid inclusions. Chemical Geology, 1987, vol. 64, pp. 335-350.

44. Bakker R.J. Package FLUIDS 1. Computer programs for analysis of fluid inclusion data and for modelling bulk fluid properties. Chemical Geology, 2003, vol. 194, no. 1-3, pp. 3-23. DOI: 10.1016/S0009-2541(02)00268-1

45. Azomani E., Azmy K., Blamey N., Brand U., Al-Aasm I. Origin of Lower Ordovician dolomites in eastern Laurentia: controls on porosity and implications from geochemistry. Marine and Petroleum Geology, 2013, vol. 40, no. 1, pp. 99-114. DOI: 10.1016/j.marpetgeo.2012.10.007

46. Bodnar R. J. Hydrothermal solutions. Encyclopedia of geochemistry. Eds. C.P. Marshall, R.W. Fairbridge. Lancaster, Kluwer Academic Publishers, 1999. pp. 333-337.

Received: 5 August 2020.

\section{Information about the authors}

Lyubov A. Krasnoshchekova, Cand. Sc., associate professor, National Research Tomsk Polytechnic University.

Aura S. Garcia, postgraduate student, National Research Tomsk Polytechnic University.

Vladimir B. Belozerov, Dr. Sc., professor, National Research Tomsk Polytechnic University. 